\title{
Women Empowerment in Select Novels of Ian McEwan
}

Deepati Pant

Research Scholar, Department of English

Motiram Baburam Govt. Post Graduate College Kumaun University

Nainital, Uttarakhand, India

pantdeepti602@gmail.com

Dr. Kavita Pant

Guide, Assistant Professor, Department of English

Motiram Baburam Govt. Post Graduate College Kumaun University

Nainital, Uttarakhand, India

Abstract

This article is an attempt to trace women empowerment in select novels of Ian McEwan. It is through this article that I would present the empowered female characters in Ian McEwan's novels The Cement Garden (1978) and Nutshell (2016). These three novels are different from each other in their material, plot and characterization. But these novels bear a unique similarity. These novels show highly empowered female figures who have endowed with amazing capacity of head and heart. His novels show that Ian himself advocates power shift from male to female. It is because of this advocacy Ian appears to be a feminist. The Cement Garden belong to the early phase of Ian McEwan while Nutshell belongs to the later phase of Ian McEwan. Unique thing that captures our attention is the presence of empowered female characters in both the novels. 
Keyword- Feminist, Domination, Oedipus Complex, Empowerment, Power Shift, The Cement Garden and Nutshell.

The Cement Garden (1978)

This novel was published in 1978 and later adapted into a 1993 film of the same title. In this novel we have a family of four children. Father dies due to heart attack and soon after his death, mother also dies. Now the four guardians less kids remain in the same home without any elderly supervision. To avoid their entry into the orphanage, they decide to bury the cement coated dead body of their mother into the cellar of their home. Two elder siblings, Jack and Julie indulge in incest. After some time, a boy Derek, takes entry in Julie's life. This entry was intolerable for brother Jack. He became jealous of Julie's love life. In the end Derek, discovers some secret of the family regarding the grave of mother in to the cellar. In the end police arrives at the home to gain custody.

The spirit of feminism finds full and candid expression in the novels of Ian McEwan. Through his works he tries to impart same degree of freedom, power and position to female as is bestowed upon male by our society. Ian McEwan through his works try to impart full length and position to females so that they may glitter in their powerful roles. The Cement Garden and Nutshell have been written by him in different time period. In this period a huge change was being faced by society regarding the status of fair sex. Ian McEwan's own experiences get reflected in his novels. It becomes highly amazing to notice that writer's own mother suffered bitterly the undue suppression of her husband. The son imparted powerful roles to the female characters in his novels with the magic of his pen. Ian has a deep sympathy for his mother and he feels that his father has tortured his mother and through his works he tries to liberate womenfolk from the clutches of men. In doing so he tries to liberate his mother. This type of sympathy is reflected in Jack's feelings for his mother. The same feeling had been expressed in the following lines. Ian admits: 
In my 20s I was often defending or trying to defend, Rose against David, or promote her cause somehow. The effect on my writing was faintly direct; though I think at the time I had no clear sense of the connections. I've read the 'Female Eunuch' in 1971 and or it was a revelation. The feminism of the 1970s spoke directly to a knot of problems at the heart of our family's life. I created a romantic vision that if the spirit of women was set free, it would heal the world. My stories female characters represented all the good traits that men were lacking. In other words, pen in hand, I was going to set my mother free. (Mother Tongue)

Narrator wants sole possession in his mother's love in The Cement Garden. Here we find the direct glimpse of "Oedipus complex". In this novel; we can easily trace out the very complex in Jack's and Tom's mind. They do not want to share their mother with anyone else not even with their father. Due to his father's ill treatment, narrator becomes over protective towards his mother and his mother is also well acquainted with her son's mentality. As Jack admits "She knew I had come home to monopolies her while my father and two sisters were out of the house. Perhaps she was glad to have someone at home with her during the day." (CG 22) Actually Ian tries to empower his female characters in his work, with an intention to liberate women folk.

In his debut novel The Cement Garden we can find out Julie as the epitome of female dominance. Jack is a male character, still remains under the shadow of his sister. Actually, Ian himself has admitted presence of two dominant ladies in his life. One was his previous wife Penny Alan and second was his mother. Through his work he tries to show the dominating nature of female characters. In The Cement Garden, Julie handles the house-hold affairs without the assistance of her brother. She replaces her mother, and becomes a fullfledged head girl of the home. 
She takes care of her home beautifully. Her mother also shows her full confidence in her daughter's ability and assigns duties on her shoulders. She takes part in schools sport even though; in this she never gets support from her father. She does not wait for his father's consent and does not shed tears on his demise. She, like a leader tries to lead the family. In fulfilling his duties towards her home, she also fulfils her obligation towards her own life. She involves in a romantic affair with Derek and enjoys life in the best manner. After his mother's demise, it was Julie, who decides to give her mother, a home burial. She does not become emotional and it appears that she is already prepared to deal with the situation.

She buys costly jackets and boots for herself. She orders her brother like a master. Jack also feels impotency of his personality under Julie's regime. It was Julie who grants Tom's wish to be a girl. Actually, Tom's wish to be a girl shows a power shift in the household. The authority, which had been earlier enjoyed by Julie's father, has crowned on Julie's head after his demise. Julie does not care for the displeasure of Jack and invincibility rules in her home and casts a powerful impact on readers. Jack does not like Tom's transformation into a girl but these objections are vehemently retorted by Julie. She highlights the hidden hypocrisy of Jack's mind:

But for a boy to look like a girl is degrading, according to you, because secretary you believe that being a girl is degrading. Why else would you think its humiliating for Tom to wear a Frock? (CG 48)

Derek's entry in Julie's life brings freshness but very soon this fresh breeze makes her bored. She loves her freedom more than anything else. Oppression of mother has exercised a powerful impact on the growth of Ian McEwan. Since as a son Ian McEwan could not provide justice to his mother so he tried to liberate her mother through his works. Most of McEwan's male protagonists are in fact, insecure men, unable to admit their incapacities for 
they are too blended by their belief in their unavoidable fate as natural leader (Smejkhalova10)

Female characters of Ian McEwan's early phase represent more power in comparison to their male counterparts. This power is endowed on them by the pen of novelist, who has witnessed this powerful role of ladies in the form of his first wife. Actually, Ian McEwan's first wife has filled a divorce and then a custody case against him. It is at this time that he realized the full power of a female, never showed by his mother against his father. It has made him to realize the invincible power of female and he has expressed it through his novels. The domination of his first wife is aptly wrapped in the following lines:

Despite the fact that she failed in the end, the effort and the duration of the pressure was the proof of her great strength and power. She demonstrated her husband something unknown and something he had not experienced until that time. In an interview Mr. McEwan even described his ex-wife as the single most important influence on his work.

(Koblizkova)

Thus, we can say that all the bold ladies portrayed by him in his novels bear powerful tie with his first wife. "She is a very strong presence in my life, emotionally, sexually and this emerges in my work" (Mail Online) Ian McEwan's anti- father psyche is also reflected in his work penned by him in his early phase and such psyche is dominant in, his debut novel The Cement Garden. Leading characters of this novel contain anti- father psyche and directly admit their resemblance with the novelist. For example, Jack is a leading character in his debut novel The Cement Garden. He does not like his father at all. Even his sisters do not have any feelings towards their father. Their father's death was a type of freedom for them. Female characters on the other hand are daring. They do not feel any hesitation in expressing their feelings to others. Ian McEwan gives proper weight to his female characters and they "perpetually undermine the patriarchal illusion" (Smejkalova 10) 
Julie manages everything as per her norms. She goes for shopping the novelist describes her personality - " She could run faster than anyone, I know father had never taken his seriously, he said it was daft in a girl, running fast and no long before he died, he refused to come to a sports meeting with us (CG 10) These lines show her father's low opinion about his daughter Julie is a girl with a modern outlook. She remains conscious about her outfits "She had boyfriend at school, but she never really let them get near her, her closest friends were girls, the most rebellious, and the one with reputation (CG16,17).

Jack admits her powerful role in chapter 2. "She dominated her group and heightened her reputation with a disruptive intimidating quietness." Jack feels his own life overshadowed by Julie's gigantic image. " I had some status at school as Julie's brother but she never spoke to me there or acknowledge my presence "(CG17) Julie fulfils all her duties and does not allow her younger brother Tom to enter in her sleeping mother's room. She helps Tom to wear a frock as per his wish she says- "You think it's humiliating to look like a girl, because you think it's humiliating to be a girl." (CG48)

After mother's death Julie remains calm, she cries only after she's crying while Jack cries immediately not because of the loss of mother but the loss of power. "I am in charge; too, I said and begin to cry because I felt cheated. My mother had hone without explaining to Julie what she had told me (CG 53) Tom's transformation from a boy to a girl is remarkable in the sense of female empowerment in household. Slowly and slowly, he accepts his girlish outfits. When Julie ties a ribbon around Jack's neck, he does not object.

In this way Julie not only occupies the lead role but also curbs the raising head of patriarchy and successfully enjoys her pivot role in family. Julie employs Jack in household Jobs and also asks him to massage her body. Jack says: when I had finished shed called over her shoulder "Now do my legs" (CG 44) When Julie's boyfriend Derek tries to dominate her, she becomes fed up with his bloke. Then she once again provokes Jack's emotions. Julie is a 
mastermind who dominated her brother and boyfriend. Jack and Derek are puppets in her hand. Julie is smart enough to know when to pull the string. She remains independent from beginning to the end she has a personality of her own. She smokes openly. When Jack feels exhausted in burying mother's dead body, she helps him. She is quick witted. She illuminates her role as a leader of her family after her parent's death.

Women Empowerment in Nutshell (2016)

This novel is retelling of Shakespeare's Hamlet. It is the $14^{\text {th }}$ novel by English author Ian McEwan, published in 2016.This story is presented from the perspective of an unborn baby. This unborn baby is the main narrator who overhears the toxic relationships that exist between his parents. He is aware of the fact that his uncle is in illicit relationship with his mother. His mother is an ambitious lady with least affection for her own husband. His mother together with her brother-in-law hatches a conspiracy to murder her husband. She gives a poisonous smoothie to her husband as a result of which her husband dies. Towards the end of the novel wrongdoers was captured by the police. Before their escape, baby's delivery takes place giving them no time to escape from their punishment. In this way this newborn baby avenges the wrongdoers. The novelist borrowed the title from Shakespeare's Hamlet.

Before highlighting the powerful role played by the female character let us discuss the plot. In this novel ewe have an inborn male baby who listens notices, reacts various ideas and feelings of his pregnant mother. From the beginning, Trudy remains a dominant character and tries to maintain this characteristic throughout the novel. She gives plan to Claude. She is also well acquainted with the fact that Claude doesn't have a good brain. It is Trudy who suggests him to murder her husband. She wants her ownership in property. First, she dominates her husband then she tries to dominate Claude. John Cairncross couldn't do anything despite knowing the treacherous character of his wife. It would be called an irony that despite 
knowing everything about Trudy, he wants reunion with her. Trudy lives with her brother-inlaw immorally but becomes infuriated to find a new girl's entry in her husband's life and becomes desperate to murder him. Here we can find out the double standard of Trudy that allows her to maintain illicit relationship with Claude but never permits relationship of another girl with her husband. Her character is filled with jealousy, hatred, treachery, lust and materialistic thinking. She has an abnormal lust for physical intimacy. Even when she comes to know about the death of her husband, she enjoys physical intimacy with her brother-inlaw. She represents declining moral values and faded humanity in females.

She does not like her husband intimacy with a new girl Elodie. Her hatred for this new girl is well depicted. “The two women don't embrace or even touch or speak when they are inches apart" (NT138) But her feeling towards Claude is also ambivalent. In one point of the story, when Elodie comes in her home to console her, Claude offers his shoulder to Elodie. But this soft nature of Claude towards Elodie disturbs Trudy. She has become very possessive of Claude and does not want to share Claude with any other lady. "My mother stays at the foot of the stairs, is stiffening with distrust, not only of the visitor. So, it's bardic distress" (NT137)

Trudy is the modern version of Gertrude. Gertrude in Shakespeare's Hamlet was submissive but Trudy in Nutshell is a bold lady who does not like her husband and prefers to live with her brother-in-law Claude. Claude is modern Claudius, who along with Trudy hatches a murder plan of his brother John Cairncross They poison John through a fruit drink and John dies. The guilty manipulates the evidences and try to give impression of suicide.

Trudy is a powerful lady. She is the one who has the courage to reject her husband. She without and hesitation lives with Claude. She loves reading like her sophisticated taste "And she likes podcast lectures and self-improving audio books know your wine in fifteen parts, biographies of seventeenth century, playwrights, and various words classics. James 
Joyce's Ulysses sends her to sleep even as it thrills me. (NT 4) She is pregnant but does not hesitate to take alcohol. "Choose the wine darling something splendid."(NT 19) Trudy has her own limits she is equally concerned about her state and does not take more than two glasses. Narrator says: "She never takes a third and it wounds me. I have to think of baby. I hear her say as she covers her glasses with a priggish hand. And I love her how could I not?"(NT 7)

When John Cairn cross tries to reunite with her and says "Look we really must talk." She says "I need more time. Try to be considerate. I am bearing your child, remember."(NT 5) Generally lady becomes emotional during pregnancy but Trudy is a lady of dominant nature. She rejects to live with her husband and without any shame lives with Claude when Trudy and Claude hatch a conspiracy to kill John, she shows her daunting nature. "She's been thinking about this thinking without knowing she is a tigress." (NT 60)

She is a lady who can do anything to gain her aim. When Trudy comes to know about the entry of another woman's entry in her husband's life, she becomes Jealous She says " I want him dead and it had to be tomorrow. "She prepares the warp and woof of the conspiracy and orders Claude like a cunning master mind "Put it in the Fridge. Hide those paper cups. Do not touch them without your gloves". (NT 79) She is a lady of controlling power and leadership quality. She makes Claude to work according to her own plan. She is fully aware of Claude's nature and hides his passport. In the last chapter when her water bag leaks, she asks Claude to assist. But Claude does not care for that and carries on his search for his passport. She says "I hid it downstairs just in case this happened". This statement shows her true nature. She lives with Claude and is fully aware that the person who has ditches his brother may prove faithless. She does not plead but orders like master. She says to Claude then you will have to be the midwife. She instructs Claude regarding the immediate nursing of a new born baby. Her knowledge regarding the carrying of an infant is amazing. 
Conclusion

Thus, we can say that Ian McEwan has portrayed very illuminating empowered female characters. These females are highly powerful as they know how to manage any difficult situation. Ian McEwan though a male writer, shows full reverence towards female characters by providing them powerful roles. His women are not feeble or waxen images controlled by men. On the contrary women are bestowed with full power by the novelist. I would like to conclude that McEwan has presented a galaxy of strong women of 20th century. In The Cement Garden and Nutshell, we have empowered female characters in the form of Julie and Trudy. These characters are independent and dominant and assert their superiority before the readers. These female characters show the magnitude of women empowerment 


\section{References}

McEwan, Ian. The Cement Garden. London: Jonathan Cape, 1978.

McEwan, Ian. Nutshell. London: Jonathan Cape, 2016.

Koblizkova, Jitka. Donination of Women over Men According to Ian McEwan. Bachelor thesis. Masaryk University.Bruno.2016.https://www.google.com/url?sa=t\&source=web\&rct=j\&url=ht tps://is.muni.cz/th/ehm0j/Jitka_Koblizkova_-

_Bachelor_Thesis_2.docx\&ved=2ahUKEwisuriH8LuAhUUwzgGHT5AD6wQFjAAegQIAhAB\&usg=AOvVaw2FnfWDphMqD2BDOfg4ZOh/ Accessed on 17 June 2020.

http://www.ianmcewan.com/resources/articles/mother-tongue.html/ Accessed on 17 July 2020.

Smejkalová, Šárka. “Characters' Transformations in Ian McEwan’s Works.” MA thesis Brno:Masaryk University, 2007/ Accessed on 28 June 2020. 